\title{
CASE COMMENT: WINNIPEG CONDOMINIUM v. BIRD CONSTRUCTION - RECOVERY OF PURELY ECONOMIC \\ LOSS IN THE TORT OF NEGLIGENCE: LIABILITY OF BUILDERS TO SUBSEQUENT PURCHASERS FOR CONSTRUCTION DEFECTS
}

\section{NICHOLAS RAFFERTY*}

\section{INTRODUCTION}

In recent years, the Supreme Court of Canada has taken a refreshingly independent approach to the determination of the proper scope of the tort of negligence. In particular, it has remained wedded to Lord Wilberforce's broad test from Anns v. Merton London Borough Council' for the determination of when a duty of care should be imposed in novel situations. Lord Wilberforce said:

[T] he position has now been reached that in order to establish that a duty of care arises in a particular situation, it is not necessary to bring the facts of that situation within those of previous situations in which a duty of care has been held to exist. Rather the question has to be approached in two stages. First one has to ask whether, as between the alleged wrongdoer and the person who has suffered damage there is a sufficient relationship of proximity or neighbourhood such that, in the reasonable contemplation of the former, carelessness on his part may be likely to cause damage to the latter, in which case a prima facie duty of care arises. Secondly, if the first question is answered affirmatively, it is necessary to consider whether there are any considerations which ought to negative, or to reduce or limit the scope of the duty or the class of person to whom it is owed or the damages to which a breach of it may give rise...

The Supreme Court has applied this test not just to the question raised in Anns itself, the tortious liability of public authorities for the negligent exercise of their statutory powers, ${ }^{3}$ but across the whole spectrum of potential liability in negligence. ${ }^{4}$

A prime area for the use and development of the Anns test has been the recovery of purely economic loss. Recently, the law in this area was considered by the Supreme

Professor of Law, The University of Calgary.

[1977] 2 All E.R. 492 (H.L.) [hereinafter Anns].

Ibid. at 498.

The starting point was Wilson J.'s majority judgment in City of Kamloops v. Nielsen (1984), 10 D.L.R. (4th) 641 (S.C.C.). See also Rothfield v. Manolakos (1989), 63 D.L.R. (4th) 449 (S.C.C.); Just v. British Columbia (1989), 64 D.L.R. (4th) 689 (S.C.C.); Brown v. British Columbia (Minister of Transportation and Highways) (1994), 112 D.L.R. (4th) 1 (S.C.C.); Swinamer v. Nova Scotia (Attorney General) (1994), 112 D.L.R. (4th) 18 (S.C.C.).

4 In a particularly interesting application of Lord Wilberforce's test, LaForest J., in dissent in London Drugs Lid. v. Kuehne \& Nagel International Ltd. (1992), [1993] 1 W.W.R. 1 (S.C.C.), used it to reach the conclusion that employees came under no duty of care to their employer's customer, even in respect of property damage, where their negligent conduct was related to their employer's contract with the plaintiff. In LaForest J.'s view, the customer should normally be regarded as having relied upon the employer in these circumstances rather than upon any individual employees. 
Court in some depth in Canadian National Railway Co. v. Norsk Pacific Steamship Co., ${ }^{5}$ a case concerned with the recovery of purely economic loss incurred by a plaintiff as a consequence of property damage suffered by a third party. The plaintiff was seeking to recover the cost of re-routing its trains over another railway bridge when use of its regular bridge, owned by the Crown, was interrupted following a collision with a barge being towed by the defendant's tug. Whilst the Court was divided on the main issue, with LaForest $\mathrm{J}$. and two others favouring the exclusionary rule in this context and McLachlin J. and two others granting recovery on the basis of the peculiarly proximate relationship between the parties, it was unanimous in its view that the Anns test was still the path to be taken in Canada.

In Winnipeg Condominium Corp. No. 36 v. Bird Construction Co., ${ }^{6}$ the Supreme Court was compelled to address the recovery of purely economic loss in the context of builders' (and thus inferentially manufacturers') liability for defective structures (chattels). This time the decision was unanimous. It had been foreshadowed by LaForest J.'s observation in Norsk that Laskin J.'s concern in Rivtow Marine Ltd. v. Washington Iron Works "with safety and the prevention of further damage [was] justified." ${ }^{8}$

\section{FACTS AND ISSUES RAISED}

The facts were very straightforward. The defendant was the general contractor for the construction of a 15-storey apartment building. The building was completed in December, 1974. Some four years later, the block was acquired by the plaintiff and converted into condominiums. In 1982 the board of directors of the condominium corporation became concerned about the state of the exterior stone cladding of the structure, which had been installed by a subcontractor. Following the advice of a firm of structural engineers and the original architects, some minor remedial work was carried out. Seven years later, a storey-high section of the cladding, some twenty feet in length, plunged nine storeys to the ground below. Miraculously, no one was injured. Following further inspections, the condominium corporation had the entire cladding removed and replaced at a cost of some $\$ 1.5$ million. The condominium corporation sued, among others, the general contractor in the tort of negligence to recover this cost and the case came before the courts on a motion by the contractor to strike out the plaintiff's statement of claim as disclosing no reasonable cause of action. The issue to be resolved was framed succinctly by LaForest $\mathrm{J}$. at the start of his judgment for the Supreme Court:

May a general contractor responsible for the construction of a building be held tortiously liable for negligence to a subsequent purchaser of the building, who is not in contractual privity with the contractor, for the cost of repairing defects in the building arising out of negligence in its construction?'

(1992), 91 D.L.R. (4th) 289 (S.C.C.) [hereinafter Norsk].

[1995] 3 W.W.R. 85 (S.C.C.) [hereinafter Winnipeg Condominium].

(1973), 40 D.L.R. (3d) 530 (S.C.C.) [hereinafter Rivtow Marine].

Supra note 5 at 312 .

Supra note 6 at 88-89. 


\section{BACKGROUND}

At the time that the Winnipeg Condominium case came before the courts, the leading Canadian authority was Rivtow Marine. That case in fact concerned the negligent manufacture by one of the defendants of a defective chattel, a crane, that was likely to collapse at any time. The plaintiff, for its logging operations, had chartered a barge fitted with the defective crane. It discovered that there was a problem following an inspection undertaken after a similar crane manufactured by the defendant had collapsed, killing its operators. The plaintiff was compelled to remove its crane from service at the height of the logging season in order to have it repaired.

The majority of the Supreme Court, in a judgment given by Ritchie J., was prepared to award the plaintiff damages based on the defendant's failure to warn the plaintiff that the crane was, as the defendant had learned earlier, dangerous. As a result of this failure, the plaintiff was forced to take the crane out of service during the busy season whereas, if due warning had been given, it could have had the crane repaired during the slack season. The plaintiff, therefore, recovered the extra loss of profits so incurred. The majority, however, refused to grant the plaintiff any relief for the defendant's negligent manufacturing as such. Thus, the plaintiff could recover neither the cost of repairs nor the loss of profit that would have been incurred in any event during the down time. The crane had not caused any personal injuries or property damage. In the mind of the majority, to recognize such a tortious claim would in effect be to create a contractual warranty flowing from the manufacturer to the ultimate consumer. Since the claim was thus contractual in origin, it could not be enforced against the manufacturer by a stranger to the manufacturer's contractual relationships. Ritchie J. stated:

[T] he liability for the cost of repairing damage to the defective article itself and for the economic loss flowing directly from the negligence, is akin to liability under the terms of an express or implied warranty of fitness and as it is contractual in origin cannot be enforced against the manufacturer by a stranger to the contract. ${ }^{10}$

In a vigorous dissent, Laskin J. stressed the fact that the manufacturer, through its negligence, had produced not just a shoddy article but a dangerous one. To his mind, that fact brought the case squarely within the ambit of tort law. Since a manufacturer was unquestionably liable for physical damage caused by its defective products, it should equally be liable for the economic losses incurred in rendering its products safe. He stated:

However, Washington, as the designer and manufacturer of the crane, was under an anterior duty to prevent injury which foreseeably would result from its negligence in the design and manufacture of this piece of equipment. If physical harm had resulted, whether personal injury or damage to property (other than to the crane itself), Washington's liability to the person affected, under its anterior duty as a designer and manufacturer of a negligently-produced crane, would not be open to question. Should it then be any less liable for the direct economic loss to the appellant resulting from the faulty crane merely because the likelihood of physical harm, either by way of personal injury to a third person or 
property damage to the appellant, was averted by the withdrawal of the crane from service so that it could be repaired?"

On this basis, Laskin J. would have awarded the plaintiff the total loss of profits incurred whilst the crane was being repaired. He pointed out that the rationale underlying a manufacturer's liability for negligence "should equally support such recovery in a case where ... there is a threat of physical harm and the plaintiff is in the class of those who are foreseeably so threatened."12 Moreover, there was no danger of imposing indeterminate liability on the defendant, as there could be in respect of some relational claim:

Liability here will not mean that it must also be imposed in the case of any negligent conduct where there is foreseeable economic loss.... The present case is concerned with direct economic loss by a person whose use of the defendant Washington's product was a contemplated one, and not with indirect economic loss by third parties, for example, persons whose logs could not be loaded on the appellant's barge because of the withdrawal of the defective crane from service to undergo repairs. It is concerned ... with economic loss resulting directly from avoidance of threatened physical harm to property of the appellant if not also personal injury to persons in its employ. ${ }^{13}$

Further, Laskin J. would also have awarded the plaintiff the cost of repairing the defective crane as a reasonable means of mitigating the plaintiff's recoverable economic losses, if not also on the basis of his principle of preventing threatened physical harm.

\section{ENGLISH AUTHORITIES}

Laskin J.'s judgment in Rivtow Marine proved influential to Lord Wilberforce in Anns when dealing with the liability of a local authority for negligently approving inadequate foundations. In $D$. \& F. Estates Ltd. v. Church Commissioners for England, ${ }^{14}$ however, the House of Lords clearly preferred the reasoning of the majority in reaching the conclusion that a builder owed no duty of care in respect of defects in a structure that had caused neither personal injury nor damage to other property. Lord Bridge stated:

If the hidden defect in [a] chattel is the cause of personal injury or of damage to property other than the chattel itself, the manufacturer is liable. But if the hidden defect is discovered before any such damage is caused, there is no longer any room for the application of the Donoghue $v$. Stevenson principle. The chattel is now defective in quality, but is no longer dangerous. It may be valueless or it may be capable of economic repair. In either case the economic loss is recoverable in contract by a buyer or hirer of the chattel entitled to the benefit of a relevant warranty of quality, but is not recoverable in tort by a remote buyer or hirer of the chattel. ${ }^{\text {is }}$

\section{Ibid. at 548-49.}

Ibid. at 549 .

Ibid. at 550 .

[1988] 2 All E.R. 992 (H.L.) [hereinafter D. \& F. Estates].

Ibid. at 1006, referring to Donoghue v. Stevenson, [1932] A.C. 562 (H.L.). 
He then determined that exactly the same principle should apply to real property.

In its later decision of Murphy v. Brentwood District Council, ${ }^{16}$ the House of Lords used its reasoning in $D . \& F$. Estates to overrule the actual decision in Anns as to the tortious liability of local authorities for the negligent supervision of construction work. The decision in Murphy was premised on the view that the liability of a local authority for a failure to supervise a builder with reasonable care could be no greater than that of the builder whose fault was the primary cause of the damage. The Court then relied upon $D . \& F$. Estates for the proposition that the damage suffered by the plaintiff in these negligent building cases, where the owner discovered the defect before anybody was injured or any other property was damaged, was unrecoverable purely economic loss. To impose such a liability on a builder, or on the manufacturer of a defective chattel, would constitute the creation of a contractual warranty despite the absence of privity of contract.

In reaching its decision in Murphy, the House of Lords refused specifically to draw any distinction between dangerous defects and mere defects in quality. Lord Bridge, for example, stated:

If a builder erects a structure containing a letent [sic] defect which renders it dangerous to persons or property, he will be liable in tort for injury to persons or damage to property resulting from that dangerous defect. But, if the defect becomes apparent before any injury or damage has been caused, the loss sustained by the building owner is purely economic. If the defect can be repaired at economic cost, that is the measure of the loss. If the building cannot be repaired, it may have to be abandoned as unfit for occupation and therefore valueless. These economic losses are recoverable if they flow from breach of relevant contractual duty, but ... in the absence of a special relationship of proximity they are not recoverable in tort. ${ }^{17}$

This time Laskin J.'s dissenting judgment in Rivtow Marine was specifically rejected as "wholly unconvincing."

\section{DECISION OF THE MANITOBA COURT OF APPEAL}

In a judgment rendered by Huband J.A., the Manitoba Court of Appeal ${ }^{19}$ unanimously endorsed the contractor's position and struck out the plaintiff's claim. In so doing, the Court simply applied the reasoning of the House of Lords in $D . \& F$. Estates, a case which it found to be indistinguishable. Very little consideration was paid to any alternative argument that builders should be responsible to subsequent owners for defects in their structures. There was not even the suggestion that $D . \& F$. Estates might be distinguished on the ground that the defect there, loose plaster on the ceiling and walls, was not nearly as dangerous as that evident in Winnipeg Condominium itself.

16 [1990] 2 All E.R. 908 (H.L.) [hereinafter Murphy].

$17 \quad$ lbid. at 926.

18 Ibid. at 927, Lord Bridge.

19 [1993] 5 W.W.R. 673 (Man. C.A.). For commentary on this decision, see P. Osborne, "A Review of Tort Decisions in Manitoba 1990-1993" (1993) 22 Man. L.J. 191 at 192-98. 
Indeed, Rivtow Marine was not considered at all. Huband J.A. justified his denial of the builder's liability on the basis of the caveat emptor principle. He stated:

The concept of "buyer beware" tells the potential purchaser that if it seeks greater protection than its own investigators, inspections and inquiries provide, it should seek appropriate warranties from the vendor or, if that cannot be bargained, to seek out an insurer to cover anticipated future risks. ${ }^{20}$

The only concession made to Canadian authorities in the field was the recognition that Lord Wilberforce's prima facie duty of care test from Anns was still generally applicable in Canada, ${ }^{21}$ as was his actual decision with respect to the liability of local authorities for purely economic loss. ${ }^{22}$ The liability of local authorities, therefore, was independent from the liability of builders ${ }^{23}$ and did "not constitute a valid precedent to resolve claims by subsequent owners against the contractor at the time of construction.....24 The Manitoba Court of Appeal, however, did not rely in any way upon the fact that the Supreme Court in the Norsk case had explicitly rejected the narrow approach to the recovery of purely economic loss in negligence adopted by the House of Lords in Murphy.

\section{DECISION OF SUPREME COURT}

In a judgment delivered by LaForest $J$., the Supreme Court unanimously reversed the decision of the Manitoba Court of Appeal. First, LaForest J. reiterated his conclusion from Norsk that the issue of the recovery of purely economic loss should not be considered globally. Rather, it should be approached on a category by category basis since different policy considerations were relevant within the different categories in which the problem arose. The present case fell within the category of the negligent production of defective chattels or buildings.

Secondly, LaForest J. rejected $D . \& F$. Estates as having strong persuasive force in the Canadian context. The concern expressed by the House of Lords with the undermining of contractual principles by the imposition of tortious liability was inconsistent with the Canadian trend, starting with Central Trust Co. v. Rafuse, ${ }^{25}$ of recognizing overlapping contractual and tortious duties. He saw any duty in tort owed by the builder as independent from any contractual obligations:

The duty in tort extends only to reasonable standards of safe construction and the bounds of that duty are not defined by reference to the original contract. Certainly, for example, a contractor who enters into a contract with the original home owner for the use of high-grade materials or special omamental features in the construction of the building will not be held liable to subsequent purchasers if the building does not meet these special contractual standards. However, such a contract cannot absolve

Ibid. at 685.

For this proposition, Huband J.A. cited Norsk, supra note 5.

See City of Kamloops v. Nielsen, supra note 3; Rothfield v. Manolakos, supra note 3.

It was this proposition that had been rejected by the House of Lords in Murphy when it overruled Anns.

Supra note 19 at 681 .

(1986), 31 D.L.R. (4th) 481 (S.C.C.). 
the contractor from the duty in tort to subsequent owners to construct the building according to reasonable standards. ${ }^{26}$

Moreover, $D . \& F$. Estates was an important link in a chain of English authorities, culminating with Murphy, that had ultimately overruled Anns and severely restricted the recovery of purely economic loss in negligence. This was not the path that had been trodden in Canada.

Having thus disposed of $D$. \& F. Estates, LaForest J. proceeded to apply Lord Wilberforce's two stage test from Anns. In so doing, he emphasized the fact that the defects in this case had rendered the building dangerous to persons and other property and not merely shoddy or substandard. He expressly left open the question of whether contractors should also owe a duty to subsequent owners to repair non-dangerous defects in buildings. In the case of dangerous defects, the imposition of a tortious liability would serve to encourage repairs and thereby to protect occupants of buildings from bodily injury. In this regard, LaForest J. adopted the reasoning of Laskin J. in Rivtow Marine and thus, inferentially, rejected Ritchie J.'s majority judgment. He stated:

If a contractor can be held liable in tort where he or she constructs a building negligently and, as a result of that negligence, the building causes damage to persons or property, it follows that the contractor should also be held liable in cases where the dangerous defect is discovered and the owner of the building wishes to mitigate the danger by fixing the defect and putting the building back into a non-dangerous state. In both cases, the duty in tort serves to protect the bodily integrity and property interests of the inhabitants of the building. ${ }^{27}$

On this basis, it was easy for LaForest $\mathrm{J}$. to establish a sufficient degree of proximity between the parties so as to satisfy the first branch of the Anns test. He stated:

By constructing the building negligently, contractors ... create a foreseeable danger that will threaten not only the original owner, but every inhabitant during the useful life of the building. ${ }^{28}$

Thus, builders were prima facie under a duty in tort to subsequent owners for the cost of repairing defects that posed "a real and substantial danger to the inhabitants of the building." ${ }^{29}$

LaForest J. then determined, within the second limb of the Anns test, that there were no considerations that ought to negative or reduce the contractor's duty in any way. First, any concern that the imposition of tortious liability might subvert contractual relationships and the doctrine of privity of contract had little foundation when the structure in question was dangerous rather than merely constructed below some

$26 \quad$ Supra note 6 at 99.
27
$28 \quad$ Ibid. at $106-07$.
$29 \quad$ Ibid. at 106.
Ibid.


contractual standard of quality ${ }^{30}$ On a more general level, any such duty on the part of a contractor would not expose the defendant to a "liability in an indeterminate amount for an indeterminate time to an indeterminate class. ${ }^{.31}$ The class of potential plaintiffs was restricted to future inhabitants of the building. The amount of recovery was restricted to the reasonable cost of restoring the building to a safe state. The time was restricted to the useful life of the building.

Secondly, the doctrine of caveat emptor was no reason to deny a duty in tort. The assumption underlying that doctrine was that the ultimate purchaser was better placed to detect problems and thus to bear the risk of rectifying hidden defects. The original builders, however, were in the best position to ensure the structural stability of their buildings and the imposition of a tortious duty served as an important inducement to builders to ensure that their work was properly executed.

Thus, LaForest $\mathrm{J}$. concluded that the contractor could, in principle, be liable for the reasonable cost of putting the building into a non-dangerous state.

\section{ANALYSIS}

LaForest J.'s reasoning in favour of granting relief in respect of dangerous defects is persuasive. In recognizing such a duty in tort, there is no greater danger of undermining contractual relationships than there was in Donoghue v. Stevenson itself. As has been pointed out, "the refusal to permit recovery for potentially dangerous product defects provides the product user with a very perverse set of incentives to avoid the harm." ${ }^{32}$ It is interesting to note that, in Rivtow Marine, Laskin J. was willing to award the plaintiff the cost of repairing the crane primarily as a reasonable means of mitigating the consequential loss of profits to be incurred by the plaintiff. In Winnipeg Condominium, the plaintiff was in principle awarded the cost of repairs directly on the ground of the avoidance of physical damage. It had not advanced any claim for consequential economic losses. Presumably, these too would potentially have been recoverable if not too remote. ${ }^{33}$

Of course, there will be difficulties in future cases in determining just when a building constitutes a "real and substantial danger" to its inhabitants and in distinguishing between buildings that are dangerous as opposed to merely substandard. In practice, this latter distinction may prove impossible to draw. Also, the courts will have to address the question of what repair costs are recoverable. LaForest $\mathrm{J}$. said that the plaintiff would be entitled "to recover the reasonable cost of putting the building into a non-dangerous state, but not the cost of any repairs that would serve merely to

Ibid. at 111-12.

31 Ibid. at 111, LaForest J., quoting Cardozo C.J. in Ultramares Corp. v. Touche, 174 N.E. 441 at 444 (N.Y. Ct. App. 1931).

32 B. Feldthusen, Economic Negligence: The Recovery of Pure Economic Loss, 3d ed. (Toronto: Carswell, 1994) at 191.

33 See B. Feldthusen, "Winnipeg Condominium Corporation No. 36 v. Bird Construction Co.: Who Needs Contract Anymore?" (1995) 25 Can. Bus. L.J. 143 at 145. 
improve the quality, and not the safety, of the building." ${ }^{34} \mathrm{He}$ did make it clear, however, that he would not accept the logic of the House of Lords in Murphy to the effect that a plaintiff could always avoid any danger by discarding the house or chattel in question, and that as a result, a dangerous defect, once revealed, was no longer dangerous. LaForest $\mathrm{J}$. pointed out that owners do not have a realistic choice of discarding their homes when they prove to be a source of danger. Even if they do, that should not prevent them from recovering the cost of replacement. In most cases, however, the natural, and most cost-effective, choice would be to repair the defect.

The interesting question is whether, in the future, the Supreme Court will be prepared to take the further step of imposing a tortious duty on contractors to produce buildings that are reasonably fit and habitable. While LaForest J. expressly left this issue open, there are signs that he would be sympathetic to such a development in the law. Thus, his judgment was heavily influenced by an article of Sir Robin Cooke, the President of the New Zealand Court of Appeal, in the Law Quarterly Review. ${ }^{35}$ Sir Robin Cooke clearly favoured the recognition of some general duty of care owed by builders to subsequent purchasers. LaForest $\mathrm{J}$. quoted ${ }^{36}$ with apparent approval the conclusion to that article:

The point is simply that, prima facie, he who puts into the community an apparently sound and durable structure, intended for use in all probability by a succession of persons, should be expected to take reasonable care that it is reasonably fit for that use and does not mislead. He is not merely exercising his freedom as a citizen to pursue his own ends. He is constructing, exploiting or sanctioning something for the use of others. Unless compelling grounds to the contrary can be made out, and subject to reasonable limitations as to time or otherwise, the natural consequences of failure to take due care should be accepted. ${ }^{37}$

With those words, Sir Robin Cooke echoed the sentiments that he had expressed some fifteen years earlier in Bowen v. Paramount Builders (Hamilton) Ltd. in the following manner:

I do not see why the law of tort should necessarily stop short of recognising a duty not to put out carelessly a defective thing, nor any reason compelling the courts to withhold relief in tort from a plaintiff misled by the appearance of the thing into paying too much for it ${ }^{38}$

Most recently, in Invercargill City Council v. Hamlin, ${ }^{39}$ the New Zealand Court of Appeal seemed to accept that, despite Murphy, builders would continue to owe a duty of care to subsequent purchasers in respect of construction defects. Thus, Cooke P. stated:

$34 \quad$ Supra note 6 at 109.

$35 \quad$ Sir Robin Cooke, "An Impossible Distinction" (1991) 107 L.Q. Rev. 46.

36 Supra note 6 at $97-98$.

37 Supra note 35 at 70.

$38 \quad$ [1977] 1 N.Z.L.R. 394 at 423 (C.A.).

39 [1994] 3 N.Z.L.R. 513 (C.A.) [hereinafter Invercargill]. For commentary on this decision, see I.N.

Duncan Wallace, Q.C., "No Somersault after Murphy: New Zealand Follows Canada" (1995) 111

L.Q. Rev. 285. 
Since Bowen in 1976 it has been accepted that a duty of reasonable care actionable in tort falls on house builders and controlling local authorities, and in that case one member ${ }^{1201}$ of the Court ventured to question the value in this field of an attempted distinction between pure economic loss and damage to the building..."

On the other hand, Invercargill itself was concerned directly only with the liability of local authorities and thus the basis for any duty of care on builders was not really canvassed. ${ }^{42}$

In fact, a case can be made for the view that builders should owe a duty to subsequent purchasers to construct houses of a reasonably acceptable quality. Many of these reasons were given by Thayer J., speaking for the Supreme Court of New Hampshire in Lempke v. Dagenais, ${ }^{43}$ when he fashioned an implied warranty of reasonable quality flowing from the original builder to subsequent purchasers. Interestingly, LaForest $\mathrm{J}$. relied upon this judgment and many of the reasons given when rejecting a strict application of the caveat emptor principle. He stated:

In Lempke, ... the Supreme Court of New Hampshire made reference to a number of policy factors that strongly militate against the rigid application of the doctrine of caveat emptor with regard to tort claims for construction defects:

First, "[c]ommon experience teaches that latent defects in a house will not manifest themselves for a considerable period of time ... after the original purchaser has sold the property to a subsequent unsuspecting buyer." ...

Second, our society is rapidly changing.

"We are an increasingly mobile people; a builder-vendor should know that a house he builds might be resold within a relatively short period of time and should not expect that the warranty will be limited by the number of days that the original owner holds onto the property." ...

Furthermore, "the character of society has changed such that the ordinary buyer is not in a position to discover hidden defects..." ...

Third, like an initial buyer, the subsequent purchaser has little opportunity to inspect and little experience and knowledge about construction. "Consumer protection demands that those who buy homes are entitled to rely on the skill of a builder and that the house is constructed so as to be reasonably fit for its intended use." ...

Fourth, the builder/contractor will not be unduly taken unaware by the extension of the warranty to a subsequent purchaser. "The builder already owes a duty to construct 
the home in a workmanlike manner..." ... And extension to a subsequent purchaser, within a reasonable time, will not change this basic obligation.

Fifth, arbitrarily interposing a first purchaser as a bar to recovery "might encourage sham first sales to insulate builders from liability. ${ }^{\text {"4t }}$

In addition, Thayer J. pointed out that the builder, by virtue of its superior knowledge and expertise, is normally in a better position to evaluate and guard against the financial risks posed by latent defects. ${ }^{45}$

These reasons have force primarily in the residential home purchase market. A good case can still be made for distinguishing the liability of manufacturers of chattels ${ }^{46}$ and even that of builders where commercial purchasers are involved. ${ }^{47}$ One major problem to be faced in Canada, as recognized by LaForest $\mathrm{J}$., is the reluctance to imply warranties even in favour of the first purchaser where a builder has sold a building that was complete at the time of sale. ${ }^{48}$ This problem is part of a broader concern as to whether the tortious duty can indeed be regarded as independent of the various contractual duties arising out of the chain of contracts in place. Should a subsequent purchaser be able to recover in tort against a remote builder when that builder has protected itself by contract with the first purchaser? Should a subsequent owner be able to sue a remote builder where that owner has agreed through his or her contract with the vendor to bear the risk of latent defects?

LaForest J.'s judgment will also reopen the debate as to the correctness of the much maligned decision of the House of Lords in Junior Books Ltd. v. Veitchi Co. Ltd ${ }^{49}$ In that case, the Court held that a flooring subcontractor on a construction project could owe a duty of care to the owner, despite the lack of privity of contract, not to produce a floor that was defective but not dangerous. The Court there certainly recognized the argument that, in many ways, a building can be regarded as defective only by reference to the terms of the contract under which it was produced. Thus, Lord Fraser, for example, said:

[A] building constructed in fulfilment of a contract for a price of $£ 100,000$ might justly be regarded as defective, although the same building constructed in fulfilment of a contract for a price of $£ 50,000$ might not. Where a building is erected under a contract with a purchaser, then, provided the building, or part of it, is not dangerous to persons or to other property and subject to the law against misrepresentation, I see no reason why the builder should not be free to make with the purchaser whatever contractual arrangements about the quality of the product the purchaser wishes. However

Supra note 6 at 114. Thayer J.'s judgment in Lemke was also quoted extensively by Sir Robin Cooke in his article in the Law Quarterly Review, supra note 35 at 61-63.

Supra note 43 at 295.

See generally Feldthusen, supra note 32 at 194-204.

See generally Feldthusen, supra note 33 .

See Fraser-Reid v. Droumtsekas (1980), 103 D.L.R. (3d) 385 (S.C.C.). The courts, however, do strive to avoid the rigours of the caveat emptor doctrine in this context: see recently Strata Plan NW 2294 v. Oak Tree Construction Inc., [1994] 8 W.W.R. 49 (B.C.C.A.).

[1982] 3 All E.R. 201 (H.L.) [hereinafter Junior Books]. 
jerry-built the product, the purchaser would not be entitled to damages from the builder if it came up to the contractual standard. I do not think a subsequent owner could be in any better position...50

Equally, Lord Roskill suggested that account should and could be taken of any clauses contained in the contract between the owner and the main contractor on the following basis:

During the argument it was asked what the position would be in a case where there was a relevant exclusion clause in the main contract. My Lords, that question does not arise for decision in the instant appeal, but in principle I would venture the view that such a clause according to the manner in which it was worded might in some circumstances limit the duty of care just as in the Hedley Byrne case the plaintiffs were ultimately defeated by the defendants' disclaimer of responsibility."

One problem, of course, with this reasoning is that the subcontractor is not a party to the main contract and any clauses contained therein will not normally have been placed there by the subcontractor. However, Lord Roskill's dicta were cited with approval in Southern Water Authority v. Carey ${ }^{52}$ where the Court gave effect to an exclusion clause in the main contract that did purport to protect a subcontractor on the ground that this was a consideration within the Anns test that ought to negative the defendant's duty of care. On the other hand, Lord Roskill's dicta were doubted by Lord Brandon in Leigh \& Sillovan Ltd. v. Aliakmon Shipping Co. Ltd. where he said that no analogy could be drawn between a Hedley Byrne disclaimer which operated directly between the parties and "an exclusion of liability clause in a contract to which the plaintiff is a party but the defendant is not." ${ }^{133}$ Lord Brandon had issued a powerful dissenting judgment in Junior Books itself where he pointed out the difficulty of determining whether a product was defective except by reference to the terms of a contract to which the plaintiff was not a party. His ultimate conclusion in that case anticipated the decision of the Supreme Court in Winnipeg Condominium:

The sole question is whether the product is so defective that, when used or consumed in the way in which it was intended to be, it gives rise to a danger of physical damage to persons or their property, other than the product concerned itself.

One may also question whether Junior Books should be regarded as a form of Hedley Byrne liability though later English decisions ${ }^{55}$ have interpreted it as such, based upon the very close relationship between the parties, and thereby confined it to its special facts.

Junior Books, ibid. at 214, referring to Hedley Byrne \& Co. Ltd. v. Heller \& Partners Lid., [1964]

A.C. 465 (H.L.).

(1984), [1985] 2 All E.R. 1077 (Q.B.D.).

[1986] 2 All E.R. 145 at 155 (H.L.).

Supra note 49 at 218.

See, e.g. D. \& F. Estates; Murphy. 
Interestingly, in Invercargill, Cooke P. suggested ${ }^{56}$ that the imposition of tortious duties in the Junior Books situation might not be required because sufficient redress would be available through the various contractual relationships. ${ }^{57}$ On the other hand, he also indicated some approval of the Scottish approach which he described as follows:

[I]n Scotland, where Junior Books is still apparently treated as authoritative, it has been suggested that, where the pursuer and defender are connected by a series of existing contracts, the defender owes a duty of care to the pursuer not to perform his contract with another party in the chain in a careless way, if the defender knows the identity of the pursuer, knows that the pursuer is part of the contractual structure, and knows that as a result of the "chain reaction" of subsequent defective performance along the line the pursuer will suffer economic loss.

\section{CONCLUSION}

Given the uncertainty engendered by the decision in the Norsk case when dealing with relational economic loss, it is good to see the Supreme Court in Winnipeg Condominium speaking with one voice in the area of builders' liability for purely economic loss. The position adopted is defensible. The decision is presumably equally applicable to the liability of manufacturers for defective chattels and has, in effect if not in words, overruled the majority judgment in Rivtow Marine. In stark contrast to the Manitoba Court of Appeal, it is also gratifying to see the Supreme Court confirm again its independence from the recent conservatism evidenced by the English courts. ${ }^{59}$

The test propounded in Winnipeg Condominium, however, will certainly cause difficulties in application. The danger posed there by the exterior cladding was selfevident, but the same could not so easily be said in many other cases. Could not almost any defect be regarded as dangerous if left unrepaired for a considerable period of time? What exactly is entailed in restoring the property to a non-dangerous state? For these, if for no other reasons, the courts will have to address quickly the issue left open by LaForest $\mathrm{J}$. of whether builders (or manufacturers or subcontractors) can ever be liable in the tort of negligence for the cost of repairing non-dangerous defects. ${ }^{60}$ This question will prove much harder to resolve.

Supra note 39 at 520.

See Feldthusen, supra note 32 at 147-53.

Supra note 39 at 520-21 [emphasis in original].

There are increasing signs that this trend might well have run its course because the House of Lords, under the tutelage of Lord Goff, has become more adventurous of late in the area of negligence liability: see e.g. Spring v. Guardian Assurance plc, [1994] 3 All E.R. 129 (H.L.); Henderson v. Merrett Syndicates Lid., [1994] 3 All E.R. 506 (H.L.); White v. Jones, [1995] 1 All E.R. 691 (H.L.).

Such a liability was imposed recently on a builder by the majority of the Australian High Court in Bryan v. Maloney (1995), 182 C.L.R. 609. 